\title{
Multiculturalism in the world system: towards a social justice model of inter/multicultural education
}

\author{
Carlos Alberto Torres \& Massimiliano Tarozzi
}

\section{Crisis in the field of multiculturalism: the case of the European Union and the United States}

According to several U.S. newspapers, European multiculturalism is dead, citing the failure of public policies on multiculturalism in Northern Europe. That is, these policies have unsuccessfully integrated immigrants, and their goal of respecting or even praising cultures has not contributed to social integration. As the argument goes, multiculturalism would create separate communities and eventually promote the emergence of internal enemies within the nation. American neoconservatives look to Europe with renewed hope and enthusiasm, rejoicing in political judgments set down by heads of state Angela Merkel, David Cameron and Nicolas Sarkozy. On 17 October 2010, German Chancellor Merkel had declared in a meeting of her conservative Christian Democratic Union party that multiculturalism had 'utterly failed'. Her remark was met with a standing ovation. One year later, Prime Minister Cameron described Britain's long-standing state-sponsored policy of multiculturalism as a 'failure'. France's Sarkozy relatively espoused the same sentiment, claiming that French public policies were heavily concentrated on the culture of those who arrived and insufficiently focused on the host culture.

These pronouncements are the result of a superficial debate that follows neoconservative and populist tendencies. Such tendencies have been prevalent in a Europe concerned with growing migration, fear of Islam and historical tolerance that has been annihilated by an exceptional economic crisis. Nevertheless, other and more sensible criticisms of multiculturalism and intercultural education have emerged beyond this superficial debate, which should be considered to advance a constructive response.

Post-multiculturalist scholars (e.g., Kymlicka 2010; Banting and Kimlicka, 2013), or scholars who overcome the traditional approach of multiculturalism by recognizing its weaknesses while adhering to its fundamental aims, as well as public intellectuals have criticised multiculturalism, arguing that political theory and policies, programmes and initiatives seem to consistently retreat from multiculturalism (Wieviorka 1996; Joppke 2004; Vertovec and Wessendorf 2010; Korteweg and Triadafilopoulos 2015). A most serious backlash to multiculturalism occurred in the European Union (EU)

(Peters and Besley 2014). If some of the most strident cases of anti-multicultural public policy (e.g., Arizona anti-immigrant law) were considered, then the same sentiment could be expressed about the United States.

In this article, we refer to multiculturalism as the dominant version of the struggle to incorporate diversity in the United States, and interculturalism as the dominant model for assessing diversity in EU schools. Overall, both sets of practices and traditions have parallels. The focus of both concepts is related but not identical. Multiculturalism emerged as a response to twentieth century inter-group 
relations, addressing the challenge of racialisation or integration, and is fully ingrained in the Civil Rights Movement of the 1960s, as well as the New Civil Right Movement of the Twenty First Century (Bell 1995; Landson-Billings and Tate 1995). By contrast, interculturalism chiefly addresses the question of integration of immigrants and attempts to create intercultural mediation based on a flexible idea of culture and the pursuit of a new concept of citizenship (Abdallah-Pretceille 1999; Alleman-Ghionda 2009; Gundara and Jacobs 2000). However, both models tend to converge towards a similar situation. In the United States, exemplified in the debates about protection of the border and the recent conflicts about the draconian anti-immigration measures of Arizona and Alabama, the question of multiculturalism (and ethnic studies) has been conflated with the question of the invasion of undocumented immigrants, and therefore approximates the European situation. Very conservative sectors in the United States demand a differential integration, following the example of the majority of the European countries that do not automatically grant citizenship to the children of immigrants who are born in their territory.

Our question is not rhetorical: What type of multiculturalism is dead? The discourse about multiculturalism cannot be characterised as homogeneous and coherent. On the contrary, the ideas, policies and practices implemented under the umbrella of multiculturalism or interculturalism are too heterogeneous and diverse to be considered a monolithic model. Although multicultural education prevails in North America and more broadly in the Anglo-Saxon world and in some Northern European countries, intercultural education has spread within continental European countries as well as at the institutional level within the EU bodies' terminology (Maxwell et al. 2012).

'Intercultural education' and 'multicultural education' are two umbrella terms subsuming a number of approaches (Hill 2007). European scholars posit that intercultural education encompasses multicultural education as well as antiracist education for minorities (Alleman-Ghionda 2009). However, intercultural education has been made a monolithic model for political purposes by the establishment and politicians who are advancing agendas that may collide with some of the key proponents of multiculturalism. Creating straw man descriptions, like 'multiculturalism' has important advantages. Firstly, pushing for a particular critique of a complex and elaborated model that can be easily conveyed by mass media (particularly television) in a few seconds and with sound bytes is a simple approach. Secondly, jointly with the simplification of the discourse that may please hegemonic media outlets, such appeals to nationalistic ideals create fortresses to defend a locality, a region, a tradition, an ethnicity or a nation from 'outside' influences and threats. This approach is particularly handy when dealing with the critique of immigration and persons who are 'sans-papiers'. Our central thesis is as follows: A social justice-oriented inter/multicultural education is necessary for overcoming the contradictory implementation of current multicultural policies and practices. Otherwise, multiculturalism will remain a sliding signifier.

\section{Multiculturalism as a sliding signifier: a brief theoretical excursus}

Multiculturalism comes in various forms. Some versions have faced a serious backlash, whereas 
others are still relevant categories that can be useful for the interpretation of contemporary societies, representing effective practices for addressing diversity in several public spheres.

Multiculturalism is grounded in different political theories, such as communitarism (Etzioni 1995; Sandel 1982; Taylor 1992), critical pedagogy (McLaren 1997), critical theory (Torres 1998, 2009), critical race theory (Ladson-Billings 2004), post-structural theory (Sleeter and Grant 1999), antiracist theory (Leicester 1992), theories of subjugated knowledge (Semali and Kincheloe 1999) and post-development theory (Morrow 2008). Less radical perspectives exist in the wake of liberalism, such as human capital theory, John Dewey's liberalism and even liberalism's reworking in a postcontractual viewpoint provided by John Rawls (Rawls 1993, 2001).

Moreover, different approaches in inter/multicultural education exist. Any systematic analysis of the multiculturalism literature (Banks and McGee Banks 1995; Banks 2009; Sleeter 1996; Sleeter and Grant 1999; Nieto 1996) will show that the major goals of multicultural education vary from developing ethnic and cultural literacy (i.e., expanding the degree of information about the history and contributions of ethnic groups that traditionally had been excluded from the curriculum) to personal development (i.e., developing pride in one's ethnic identity); from changing attitudes and clarification of values (i.e., challenging prejudice, stereotypes, ethnocentrism and racism) to promoting multicultural competence (i.e., learning how to interact with people who are different from ourselves, or how to understand cultural differences); from developing basic skill proficiency (i.e., improving the reading, writing and mathematical skills of people whose ethnic/ racial/class background is different from the mainstream cultural capital that predominates in formal schools) to striving to simultaneously achieve educational equity and excellence (i.e., developing learning choices that work across different cultures and learning styles); to individual empowerment and social reform (i.e., cultivating students' attitudes, values, skills, habits, and discipline to become social agents committed to reforming schools and society with the goal of eradicating social disparities, racism, gender and class oppression, and therefore improving equality of educational and occupational opportunities for all).

Multicultural education consists of the following five stages (Sleeter and Grant 1999):

(1) Teaching the exceptional and the culturally different (1960s). This approach aimed to help students considered at-risk to fit into the mainstream of U.S. society by implementing strategies for remediating their deficiencies.

(2) Intercultural Education Movement. This undertaking was further developed into the Human Relations approach. It focused on the interpersonal relationship, aiming at reducing prejudices and conflicts among people.

(3) Single group studies. Characterised by attention to a single cultural group (women, Asian-Americans, Native-Americans, African-Americans), single group studies stimulated social action by providing information about a group and created new academic fields and subjects (ethnic studies, women's studies etc.). 
(4) Multicultural education. Multicultural education emerged in the early 1970s. It is both a specific approach and the general term describing 'education policies and practices that recognise, accept, and affirm human differences and similarities related to gender, race, disability, class, and (increasingly) sexual orientation' (Sleeter and Grant 1999, 150). The term links a wide range of issues, including race, culture, language, social class, gender and disability.

(5) Multicultural education that is multicultural and social reconstructionist. This approach emerged in the late 1970s and 1980s as a further development of the previous ones. It extended multicultural education from a simple classroom activity to the realm of social action. In the 5 th edition of their work (2008), Sleeter and Grant adopted the term 'multicultural social justice education' as an approach focused on equity and power relations.

The very meaning of social justice education is confusing and lacking in precision, and as a political pedagogical concept, deeply contested (Gewirtz 1998; Torres 1998; North 2006). Adding to these complexities, the same definition of multiculturalism as part of the 'politics of recognition' accounts for various uses. Multiculturalism is a social movement, a social and curriculum theory as well as an institutionalised set of administrative and pedagogical practices that deal with the question of diversity in schooling and higher education. The fact that multiculturalism as a state policy has been laid out on top of other layers of public policy, and what some may view as a retreat from state policies towards multiculturalism (exemplified by the statements made by politicians quoted at the beginning of this article) does not necessarily mean that the backlash against multiculturalism has spurred less multiculturalist programmes, as suggested by research on the indexes of multiculturalism analysing OECD countries by Keith Banting and Will Kymlicka. Banting and Kymlicka argue that,

\footnotetext{
Most countries that adopted multicultural approaches in the later part of the twentieth century have maintained their programs in the first decade of the new century; and a significant number of countries have added new ones. In much of Europe, multicultural policies are not in general retreat. As a result, the turn to civic integration is often being layered on top of existing multicultural programs leading to a blended approach to diversity.
}

This article reflects on the compatibility of multiculturalism policies and civic integration, arguing that more liberal forms of civic integration can be combined with multiculturalism, but that more illiberal or coercive forms are incompatible with a multicultural approach (Banting and Kimlicka 2013). Consequently, we need to clearly identify which form of multiculturalism is dead.

\section{Two versions of multiculturalism: normative versus constructive}

We propose a fundamental distinction between a normative and a constructive multiculturalism. The latter is combined with social justice education, which is intended as a radical approach, widespread in North America and in Anglo-Saxon countries in continental Europe. Although social justice education is not univocally defined, it has become almost a mantra among teachers, scholars, school authorities and social movements, particularly in the United States. However, social justice education is an inadequately and ambiguously developed concept, despite various attempts to conceptualise it 
and to ground its preconditions in various social theories relating to educational policy.

Educational theory can provide a solid answer to the conundrums of diversity in capitalist societies only by linking the concepts of multiculturalism and social justice. To support our argument, we need to start from a fundamental divide between two forms of multiculturalism, namely, normative multiculturalism and constructive multiculturalism.

Normative multiculturalism, or strong multiculturalism, emerged in the 1970s and further developed in the 1980s. It is rooted in a rigid conception of cultures as objective, immutable and reified. It assumes that cultures can be univocally defined and that members have identical forms of belonging within them. Conservatives have used this brand of multiculturalism to highlight a civilisation clash or to emphasise the need to protect national cultures from the dangerous hybridisation induced by incoming migrant cultures. However, normative multiculturalism has also been used by progressives to liberate oppressed and discriminated groups (Benhabib 2002). In the public sphere, this multiculturalism entails concessions, grants and privileges to safeguard minority cultures in various sectors (health, religion, welfare, political representation etc.), and to protect traditional languages, confessional schools or religious habits and customs. In sum, normative multiculturalism is an institutional perspective that is rooted in a political project based on a culturalized interpretation of the public sphere, requiring a rigid conception of culture.

By contrast, constructive multiculturalism, which Ralph Grillo (2007) defines 'weak multicuturalism' is rooted in a mobile conception of cultures, which are never conclusively defined but are visible in both the private and public spheres and across interpersonal relationships. According to this vision, cultures are dynamic processes that are constantly influenced by contexts, circumstances and relationships and constantly changing. Cultures are neither static nor deterministic and therefore are never an indisputable destiny for individuals and groups (Nieto 1996). Nor a given culture will be identified as an homogeneous identity without important fractures, tensions and contradictions among those who claim to belong to or are signified as part of such culture. This type of multiculturalism does not aim to reorganise society on the basis of the recognition of cultural groups' rights; instead, it seeks to establish fair rules of living together on the basis of cultural exchanges that require a rethinking of the notion of citizenship (Torres 1998, 2017).

Despite the struggles among subordinate groups that endeavour to position themselves in the context of the social struggle of civil minimums, and despite the rhetoriticians who have made academic careers speaking about various forms of multiculturalism as if they were the forefathers of a new revolutionary movement, normative multiculturalism can be considered dead, if it was ever alive. Hence, the capacity of normative multiculturalism to influence public policies, institutions, and practices outside the academic debate may be subject to variable interpretations. However, cultural diversity cannot be eliminated as one of the substantive methods of defining our individual and collective identities. Moreover, the different models of globalisations that we have experienced, particularly in the past three decades, have amplified in a gigantic soundboard like 
fashion the discussions and the contradictions of diversity in capitalist societies. Although the motto, 'unity in diversity', continues to be a reasonable approach that has animated a number of intelligent analyses of the conundrum of being different and simultaneously attempting to live together productively and peacefully (Freire 1998), two questions remain. Firstly, how should we arrive at such scenario of a reasonable articulation of interests, or of a reasonable accommodation of different religious, political, economic, social and cultural practices, or at least a peaceful model of articulation of public policy, without criminalising dissent or manufacturing consent as a method of preserving the governability of every day less governable democracies in the context of world capitalism? Secondly, What is the role of education in this scenario, both as a public policy and as school practice? Without answering these questions, the struggle for multiculturalism is a ruse, a window dressing to preserve the legitimacy of systems and legacies.

The influence of constructive multiculturalism is particularly evident in education, in which one of the conundrums of normative multiculturalism appears, that is, the theoretical conflict between culture and equality. Constructive multiculturalism should overcome the idea that respecting diverse minority groups denotes justifying social inequality. Particularly in Europe, the multicultural (normative) rhetoric has obscured the universal notion of equality stemming from the Enlightenment (Berry 2001) and therefore for some scholars has weakened the struggle affirming social justice (Touraine 1997; Fraser 1997; Tarozzi 2015).

The classical Enlightenment notion of equality, which is one of the pillars of modern liberal democracies, entails the formal equality of all citizens before the law and equal rights (i.e., the same opportunities regardless of diversities of gender, race, faith, sexual orientation or political perspective). This notion of equality, which is the basis for the idea of fair education equality (Rawls 2001) and allows democracies to fight against growing economic and social inequalities of the present globalised world (Sen 1992), has been often overshadowed by multicultural rhetoric.

By contrast, a multiculturalism focusing only on individual rather than collective rights renders the impossibility to confront some fundamental societal tensions, including discrimination, oppression and the hegemony of the majority. Through constructive perspective, culture still makes sense in socially constructed collective identities, in marking boundaries of difference between groups and in establishing power hierarchies, opportunities of inclusion or exclusion, as well as common norms and regulations based on these boundaries.

According to constructive multiculturalism, culture is not the only dimension that constitutes collective and individual identities. Moreover, cultures are not monolithic entities, but have rich internal variety and difference, tensions and contradictions. Therefore, establishing any type of intercultural dialogue entails the selection of those aspects of a culture 'that represent the widest circle of reciprocity within that culture, the version that goes furthest in the recognition of the other' (de Sousa Santos 2002, 55).

This premise may spur a model that seeks a 'reasonable accommodation' as provided by Bouchard 
and Taylor's analysis for harmonisation practices in Quebec (Bouchard and Taylor 2008).

Bouchard and Taylor assume that several factors are involved, from a crisis of perceptions (and hence the role of mass media), to anxiety over identity, to the presence of secularism and its influence in the diversity of Quebec. This model of accommodating diversity, grounded in the legal-juridical tradition of Quebec, and in the political tradition of citizenship rights and obligations, is one of the most substantive models designed in a North American society. Although such model was a subject of ample debate in Quebec and even across Canada, simply the idea of finding models of accommodating differential views in ways that could be used to the advantage of citizenship building, while simultaneously respecting the traditions and histories of those views and voices, is a mild yet remarkable example of social engineering.

In addition, constructive multiculturalism can recover the quest for equity and justice when combined with a culture-bound social justice perspective. Multiculturalism has overemphasised cultures as unique or major hallmarks of collective identities. By contrast, social justice and/or human rights approaches emphasise a concept of equality as an individual right.

Multiculturalism and interculturalism have been criticised for conflating the analyses of the social conditions and class assessment by paying excessive attention to the cultural dimension (Fraser 1997; Barry 2001; Gorski 2006). Focusing on cultural diversity is sometime viewed as superficial, rendering social inequalities untouched and fragmenting the opposition of the oppressed by preventing them from fighting together for common social goals; in other words, 'a politics of multiculturalism undermines a politics of redistribution' (Barry 2001, 8).

Multiculturalism, and even more so interculturalism, endorses a limited concept of equality (Tarozzi 2005). By 'limited', we mean relevant only to the recognition of cultural equality, ignoring the notion of equality as distributive justice. Cultural equality is not the same as equal opportunities for cultures, and overly stressing the former can result in disregarding the latter. Therefore, even within a multicultural education approach, issues of underachievement, dropouts, racism, violence and crime, to name a few, must be addressed. At the same time, social justice education cannot ignore cultural diversity and consider individuals in a neutral, homogeneous manner by ignoring the cultural aspects of identity.

Change occurs very slowly in market democracies. When the dynamics of these changes claim to address the rights of diversity and the equal dignity of all groups, recognising equal dignity for all cultural groups is inadequate. The promotion of equity within a social justice framework is therefore necessary.

Social justice education does not merely celebrate cultural diversity, but also examines and criticises the role of society's structures in creating discrimination and institutional oppression experienced by certain groups a priori limiting equal education opportunities (Torres and Noguera 2009; McDonald and Zeicher 2009).

Constructive multiculturalism can claim equity and social justice. However, intercultural dialogue 
should be considered to make constructive multiculturalism work. Emphasising the idea that we are not working in a zero-sum society, in which one group gains and the other invariably loses, is essential as well.

Change needs to be extracted through pressure, activism, defiance, critique, commotion, conflict and contradiction. The successes of the Arab Spring, Occupy Wall Street and the European Indignados are to some extent testimonies of the truism that nothing changes unless a revolutionary model exists. The aforementioned examples demonstrate that insurgent models can shake the very foundations of modern capitalist societies, revealing them as a house of cards.

The impasse between a European intercultural model unable to propose coherent policies, and a normative multicultural model stuck in the rigid notions of monolithic and segregated cultural groups, can be overcome by combining cultural diversity with a political tension between empowerment and disempowerment. In other words, cultural diversity can be considered a meaningful key for interpreting contemporary society and school reform only by linking diversity to power relations on a global scale and ascertaining how these policies exercise such power. Posing the question of cultural diversity and social equality along this continuum from empowerment and disempowerment may help identify the conditions to support intercultural dialogue based on equality.

The Enlightenment believed that we would become modern when we could eliminate cultural particularisms and pass from Gemeinschaft (community) to Gesellschaft (society) (Tönnies and Loomis [[1872] 1957). However, (late) modernity has produced differences and revitalised a romantic idea of culture, roots and community instead. In the last two decades of the twentieth century, the notion of culture has flourished and become an interpretive key for post-modernity. However, this same notion, so ambiguous and polysemous, is also taken for granted and widely used in naïve ways.

The cultural-based identity of a group indubitably exists, but it depends on several factors, some of which are not always circumscribable. Cultural identity primarily depends on power relations established within a certain context. Therefore, ethnicity can be legitimately defined in various ways, by including or excluding elements such as gender, age, class, education, productive status/ role, membership in specific organisations etc. Anthropologists suggest considering ethnic identity as no more than a 'regulative fiction', which may stimulate anthropological discourse, but is insubstantially founded (Appadurai 1996; Galissot, Kilani, and Rivera 2000). Thus, ethnic identities are always complex, plural, mixed, mobile and continuously recreated by people confronting their daily environment.

Unfortunately, both intercultural and multicultural education have ethnicized culture as a form of reductionism. In both discourses, but particularly within multicultural education, culture has been overemphasised. These approaches claim to protect the uniqueness of a culture by simplifying its features, and by default, stereotyping and prototyping its members.

Constructive multiculturalism reflects a basic epistemological principle of Paulo Freire's conscientisation 
model: We have to learn to live with tensions and contradictions but continue to work and walk towards a utopian future. By considering the tensions around the processes of empowerment and disempowerment, even across nations, we may reach an inter/multicultural social justice education paradigm, rooted in the flexible and negotiated identities well illustrated by new migrants moving within the present globalised scenario. In this manner, a constructive inter/multiculturalism can evolve into an inter/multicultural social justice education.

\section{What multiculturalism can learn from interculturalism, and vice versa}

We lack the space to adequately compare multicultural education, which prevails in North America, with the intercultural model mainstreaming in Europe1. However, we would like to offer some insights gleaned from this comparison of two different approaches. Deep historical, cultural and theoretical differences exist between these approaches, primarily in how they treat cultural differences and their ensuing social and educational responses (INRP, Institut National de Recherche Pédagogique 2007; Santos Rego and Nieto 2000; Grant and Portera 2011).

Although the intercultural model is highly problematic, the multicultural model has been widely criticised as well. The multicultural model has had the undeniable merit of moving the category of diversity from the margins to the mainstream in the social and political interpretation of contemporary society. However, it has offered a univocal response to manifold changes. At the same time, it has raised basic questions, to which it has been unable to provide adequate and convincing responses.

We argue that some strong points of the U.S. approach can respond effectively to the European weak points, and vice versa. From our perspective, the United States can teach Europe at least two lessons; in turn, the United States can learn two lessons from the European experience.

\section{First lesson: the United States reminds Europe that education is always political}

In the United States, multicultural education has had from the very beginning an eminently political character. Therefore, professionals and laymen are widely aware that schooling has to do with political decisions that are never neutral (Nieto 1996). In this sense, multicultural education cannot be understood in a social and political vacuum. Indeed, no educational philosophy is worthwhile unless it focuses on raising the achievement of all and providing students with an opportunity to become full citizens.

Diversity in the United States is a matter of fact. In this country, the diversity of race, gender, culture, disability and sexual preference makes sense as a claimto fill the gap of inequalities.Moreover, education can play a major role in promoting equality of rights and opportunities, starting from equal academic

\footnotetext{
1 A preliminary discussion of this topic is in Torres (2012) and Tarozzi (2012). A more detailed comparative analysis can be found in the book Tarozzi and Torres (2016), Global Citizenship Education and the Crises of Multiculturalism. London: Bloomsbury (2016).
} 
achievement. Public education is considered the 'great equaliser' because it is supposed to remove the barriers of class and provide all students with equal access to a similar education (Dewey 1916). By contrast, in Europe, intercultural education is a predominantly technical approach (European Council 2008). This approach is a strategy of schooling, a teaching method or at most an educative horizon that is always related more to practice than to political action. It is a perspective that operates only on the surface of phenomena and leaves untouched the profound structure of social dynamics that cultural confrontation implies Therein lies one of its chief limitations. Intercultural education faces social and political issues that neither begin nor end in the classroom.

\section{Second lesson: the EU regards immigration as substantive to the intercultural arena}

In the $\mathrm{EU}$, intercultural education has been a response to the recent issue of immigration and not a model for the integration of linguistic or cultural minorities. Immigration is considered a key issue both at the Europe-wide level and by every national state, which requires appropriate responses from the education. The total population of immigrants throughout the world is about 258 million (UN Department of Economic and Social Affairs 2017). The status of this population represents better than others the contradictions and conundrums related to diversity and its recognition. The migrant is the most realistically emblematic condition of the planetary economy and culture nowadays. However, the United States apparently lacks a deep understanding of immigration because it continues to tackle it as a local problem.

In Europe and in the United States, recent immigration is a burning global issue. By 2005, more than 35 million immigrants were living in the United States, representing 12.5\% of the total population; by 2040, one-third of all children are expected to grow up in an immigrant household (SuarezOrozco, Suarez-Orozco, and Todorova 2008).

This phenomenon is an outcome of the global economy. It is not an autonomous process unrelated to other international processes. Thus, immigration is similarly attributed to the economic involvement of rich countries in the global economy and not only to the poor socio-economic conditions of the developing countries (Sassen 1998). In this sense, measures to repel immigrants at the border and to block or deport illegal immigrants are completely useless.

The EU is not a good example of coherent and unitary policies for immigration either. Nevertheless, intercultural education is based on the acceptance of newcomers. This set of priorities has limitations but it has also stirred a huge debate and school innovations on various themes, such as the insertion of students during the school year, bilingualism and the teaching of a second language. The native language of an individual is certainly a civil rights issue, but it assumes new meanings within the European framework, in which multilingualism is a widely promoted asset for the same demographic situation. Within multilingual Europe, a widespread assumption is that in a global society, monolingualism is a dangerous anachronism and bilingualism, as a form to guarantee the 
same rights to the non-English speakers, is only a limited response.

\section{Third lesson: in the United States, multicultural education means social justice education}

In the United States, diversity and diversity recognition make sense only within a social justice framework. Multicultural education is a means of dealing with social justice issues. This factor underlies the argument that multicultural education is social justice education (Nieto 1996).

Recognising the equal dignity of cultures is insufficient. Equality must be recognised within the framework of social justice. According to the European sociologist Michel Wieviorka, no difference exists without inferiorisation and dominion; conversely, domination is a concept that cannot be employed with individuals, but only with collective categories (Wieviorka, 2001). Therefore, multicultural education aspires not only to accept and respect cultures, but also to empower students.

Moreover, multicultural education cannot be defined without specifically focusing on academic achievement for all.

In Europe, diversity and school achievement have been perceived synchronously only recently (and only after the 2006 PISA test). The adoption of a limited concept of equality is one of the major shortcomings of the intercultural education practice. The European approach should pay more attention to social justice and to the socio-economic factors that influence school achievement. Paradoxically, the United States, which is growing increasingly unequal, can teach Europe that diversity and justice are not necessarily incompatible, but that these concepts can and should be combined in a workable paradigm.

\section{Fourth lesson: in the EU, cultural hybridisation is at the centre of the debate}

The prevailing education approach in Europe intentionally emphasises the prefix 'inter' to outline the special attention paid to the relationship, the exchange, the dialogue among cultures, as well as their mixing. By contrast, U.S. multiculturalism has stiffened the cultures. As provocatively denounced by Pierre Bourdieu, the debate on diversity has been monopolised by a North American approach (Bourdieu and Wacquant 1999), and hence disregards the phenomena of hybridisation, mixture and creolisation typical of the European debate.

Metissage, which allows not only the reproduction but also the production of the difference, cannot find any political or juridical expression (Amselle 1998; Gruzinski 1999). However, multiculturalism does. It offers political responses to recognition demands. Nevertheless, in doing so, multiculturalism may end up petrifying differences. The evaluation of the hybrid dimensions of individuals as members of a group without losing subjectivity or the membership to a collective difference is possible on the educational plane, in particular the artistic and creative ones. 


\section{Epilogue}

From the previous analysis of the parallel outcomes of the U.S. and EU traditions, and the new winds of change in Asia considering questions of diversity and equity, we realise that a historical impasse has occurred. On the one hand, if we emphasise dialogue, hybridity and a weak notion of culture, then we fail to underline the quest for equity and justice endorsed by the U.S. multiculturalism. On the other hand, if we highlight the political dimension at the bottom of the cultural claims, then we support a social separation among groups and an unacceptable cultural essentialism, as the European approach has illustrated.

This antinomy has induced a new conservatism, which, traditionally hostile towards enhancing cultural pluralism, has now taken advantage of the anti-immigrant and anti-multicultural political climate. This backlash against multiculturalism is expected to occur in Asia once multiculturalism is fully implemented in the educational systems. The easiest responses of populist governments and some intellectuals that are organic to them are to reject the idea of cultural difference and to clamour for common values, trans-cultural universalism and national identity, which can protect the Western world from all types of enemies, including terrorists, the poor and un-assimilable immigrants.

We think differently. We believe that diversity remains a key concept for understanding the contemporary world; it is constantly mobile and complex and should be combined with the equality of rights. We deem that education can play a major role in understanding diversity.

In this article, we addressed a distinction between constructive and normative multiculturalism. Although the latter is dead in the education field, the former, based on a weak idea of dynamic and relational culture, remains an effective approach for addressing diversity in public policies and practices. In particular, the approach helps us understand the complex migration processes impacting contemporary democracies. Constructive multiculturalism that combines a flexible, mobile and different idea of cultural identity with a claim for equity and social justice against discrimination and oppression, can set the premises for building education policies and practices that are oriented towards an equitable and fair intercultural dialogue.

Through our comparative and international analysis, we seek to provide a sense for hope even in the context of the worst economic and environmental crises of our generation; even when education is being discounted as a solution to these emerging and multifarious crises; and even when some people believe that the organised governance models that have succeeded to maintain the tension between democracy and capitalism at a manageable level do not work any longer (Fukuyama 2012). Despite the odds, Eduardo Galeano's words quoting his friend Fernando Birri invite us to utopia, a fitting ending for this article: 
It is to cause us to advance ${ }^{2}$.

\section{References}

Abdallah-Pretceille, M. 1999. L'éducation Interculturelle. Paris: PUF.

Alleman-Ghionda, C. 2009. "From Intercultural Education to the Inclusion of Diversity: Theory and Policies in Europe.” In The Routledge International Companion to Multicultural Education, edited by J. A. Banks, 134-145. London: Routledge.

Amselle, J.-L. 1998. Mestizo Logics: Anthropology of Identity in Africa and Elsewhere. Mestizo Spaces. Stanford, CA: Stanford University Press.

Appadurai, A. 1996. Modernity at Large: Cultural Dimensions of Globalization. Minneapolis, MN: University of Minnesota Press.

Banks, J. A. 2009. The Routledge International Companion to Multicultural Education. London: Routledge.

Banks, J. A., and C. A. McGee Banks. 1995. Handbook of Research on Multicultural Education. New York: Macmillan. Banting, K., and W. Kimlicka. 2013. Is There Really a Retreat from Multiculturalismpolicies? New Evidence from the Multiculturalism Policy Index. Comparative European Politics, 11 (5): 577-598.

Barry, B. 2001. Culture and Equality. An Egalitarian Critique of Multiculturalism. Cambridge: Polity press.

Bell, D. 1995. "Racial Realism - After We're Gone: Prudent Speculations on America on a Post-Racial Epoch." In Critical Race Theory: The Cutting Edge, edited by T. Delgado, 2-8. Philadelphia, PA: Temple University Press.

Benhabib, S. 2002. The Claims of Culture: Equality and Diversity in the Global Era. Princeton, NJ: Princeton University Press.

Bouchard, G., and C. Taylor. 2008. Building the Future: A Time for Reconciliation. Report of the Consultation Commission of Accomodation Practices Related to Cultural Differences. Montréal, Québec: Government of Québec Bourdieu, P., and L. Wacquant. 1999. "On the Cunning of Imperialist Reason." Theory, Culture \& Society 16 (1): 41-58. de Sousa Santos, B. 2002. "Toward a Multicultural Conception of Human Rights.” In Moral Imperialism: A Critical Anthology, edited by B. E. Hernàndez-Truyol, 39-60. New York: New York University Press.

Dewey, J. 1916. Democracy and Education. New York: Macmillan.

Etzioni, A. 1995. New Communitarianism Thinking. Persons, Virtues, Institutions and Communities. Charlottesville: The University of Virginia Press.

European Council. 2008. White Paper on Intercultural Dialogue: "Living Together as Equals in Dignity”. Strasbourg. Fraser, N. 1997. Justice Interruptus: Critical Reflections on the "Postsocialist" Condition. New York: Routledge. Freire, P. 1998. The Politics of Education. Los Angeles: University of California.

Fukuyama, F. Y. 2012. The Future of History: Can Liberal Democracy Survive the Decline of Middle Class? Accessed May 25, 2012. http://www.foreignaffairs.com/articles/136782/francis-fukuyama/the-future-of-history.

Galissot, R., M. Kilani, and A. Rivera. 2000. L’imbroglio Etnique Quatorze Mots Clés. Lausanne: Editions Payot.

Gewirtz, S. 1998. "Conceptualizing Social Justice in Education: Mapping the Territory.” Journal of Education Policy 13 (4): $469-484$.

Gorski, P. 2006. "Complicity with Conservatism: The De-Politicizing of Multicultural and Intercultural Education.” Intercultural Education 17 (2): 163-177.

Grant, C. A., and A. Portera. 2011. Intercultural and Multicutlural Education. Enhancing Global Interconntectedness. London: Routledge.

Grillo, R. 2007. “An Excess of Alterity? Debating Difference in a Multicultural Society.” Ethnic and Racial Studies 30 (6): 979-998.

Gruzinski, S. 1999. La Pensée Metises. Paris: Fayard.

Gundara, J. S., and S. Jacobs. 2000. Intercultural Europe: Diversity and Social Policy. Aldershot: Ashgate.

Hill, I. 2007. "Multicultural and International Education: Never the Twain Shall Meet." Review of Education 53 (2): 245-264.

INRP (Institut National de Recherche Pédagogique). 2007. Dossier Interculturel. Approches Interculturelles en Education. Étude Comparative International. Paris: Ed. O. Meunier.

Joppke, C. 2004. "The Retreat of Multiculturalism in the Liberal State: Theory and Policy.” British Journal of Sociology 55 (2): $237-257$.

Korteweg, A. C., and T. Triadafilopoulos. 2015. "Is Multiculturalism Dead? Groups, Governments and the 'realwork of integration'." Ethnic and Racial Studies 38 (5): 663-680.

Kymlicka, W. 2010. "The Rise and Fall of Multiculturalism: New Debates on Inclusion and Accommodation in Diverse Societies.” In The Multiculturalism Backlash: European Discourses, Policies and Practices, edited by S. Wessendorf, and S. Vertovec, 32-49. London: Routledge.

Ladson-Billings, G. 2004. "New Directions in Multicultural Education: Complexities, Boundaries, and Critical Race Theory." In Handbook of Research on Multicultural Education, edited by J. Banks, and C. A. McGee Banks, 5065. San Francisco: Jossey-Bass.

Landson-Billings, G., and W. F. Tate. 1995. “Toward a Critical Race Theory of Education.” Teachers College Record 97 (1): 47-68.

Leicester, M. 1992. “Antiracism Versus New Multiculturalism: Moving Beyond the Interminable Debate.” In Education for Cultural Diversity: Convergence and Divergence, edited by J. Lynch, and S. Modgil, 215-229. London: Farmer Press.

\footnotetext{
2 E. Galeano, 1993. Las Palabras Andantes. Mexico and Spain: Siglo XXI Editores, 2010, 310.
} 
Maxwell, B., D. I. Waddington, K. McDonough, A.-A. Cormier, and M. Schwimmer. 2012. "Interculturalism, Multiculturalism and the State Funding and Regulation of Conservative Religious Schools." Educational Theory 62 (4): $427-447$.

McDonald, M., and K. Zeicher. 2009. "Social Justice Teacher Education.” In Handbook of Social Justice Education, edited by W. Ayers, and T. Q. e D. Stovall, 595-610. New York: Routledge.

McLaren, P. 1997. Revolutionary Multiculturalism: Pedagogies of Dissent for the New Millennium. Boulder, CO:

Westview Press.

Morrow, R. 2008. "Paulo Freire, Indigenous Knowledge and Eurocentrics Critiques of Development: Three

Prospectives." In Social Justice Education for Teachers: Paulo Freire and the Possible Dream, edited by A. T.

Carlos, and N. Pedro, 81-100. Rotterdam/Taipei: Sense Publishers.

Nieto, S. 1996. Affirming Diversity. The Sociopolitical Context of Multicultural Education. 2nd ed. New York: Longman. GLOBALISATION, SOCIETIES AND EDUCATION 11

North, C. 2006. "More Than Words? Delving Into the Substantive Meaning(s) of 'Social Justice'. Education.” Review of Educational Research 76 (4): 507-535.

Peters, M. A., and T. Besley. 2014. "Islam and the End of European Multiculturalism? From Multiculturalism to Civic Integration" Special Issue of Policies Futures in Education 12: 1-15.

Rawls, J. 1993. Political Liberalism. New York: Columbia University.

Rawls, J. 2001. Justice as Fairness: A Restatement. Cambridge, MA: Harvard University Press.

Sandel, M. 1982. Liberalism and the Limits of Justice. Cambridge: Cambridge University Press.

Santos Rego, A. M., and S. Nieto. 2000. "Multicultural/Intercultural Teacher Education in Two Contexts: Lessons from the United States and Spain.” Teaching and Teacher Education 16 (4): 413-427.

Sassen, S. 1998. Globalization and its Discontents. New York: New Press.

Semali, L., and L. J. Kincheloe. 1999. What Is Indigenous Knowledge? Voices from the Academy. New York: Falmer Press.

Sen, A. 1992. Inequality Reexamined. Oxford: Oxford University Press.

Sleeter, C. E. 1996. Multicultural Education as Social Civism. Albany: State University of New York Press.

Sleeter, C. E., and C. A. Grant. 1999. Making Choices for Multicultural Education: Five Approaches to Race, Class, and Gender. 3rd ed. Upper Saddle River, NJ: Merrill Publishing Company.

Sleeter, C. E., and C. A. Grant. 2008. Making Choices for Multicultural Education: Five Approaches to Race, Class, and Gender. 5th ed. New York: Wiley.

Suarez-Orozco, C., M. M. Suarez-Orozco, and I. Todorova. 2008. Learning in a New Land: Immigrant Students in American Society. Cambridge, Ma: Harvard University Press.

Tarozzi, M. 2005. Cittadinanza Interculturale. Esperienza Educativa Come Agire Politico. Firenze: La nuova Italia. Tarozzi, M. 2012. "Inter or Multicultural Education or Both?” In Languages in a Global World: Learning for a Better Cultural Understanding, edited by B. D. Chiesa, J. Scott, and C. Hinton, 393-406. Paris: OECD.

Tarozzi, M. 2015. Dall'intercultura alla giustizia sociale. Per un progetto pedagogico e politico di cittadinanza globale. Milano: Franco Angeli.

Tarozzi, M., and C. A. Torres. 2016. Global Citizenship Education and the Crises of Multiculturalism. London: Bloomsbury.

Taylor, C. 1992. Multiculturalism and the Politics of Recognition. Princeton, NJ: Princeton University Press.

Tönnies, F., and C. P. Loomis. [1872] 1957 . Community, Society. East Lansing: Michigan State University Press.

Torres, C. A. 1998. Democracy, Education, and Multiculturalism: Dilemmas of Citizenship in a Multicultural Society. Lanham, MD: Rowman \& Littlefield Publishers.

Torres, C. A. 2009. Globalizations and Education. Collected Essays on Class, Race, Gender, and the State. New York: Teachers College Press.

Torres, C.A. 2012. "The Secrets Adventures of Order: Globalization, Education and Transformative Social Justice Learning.” Asia Pacific Journal of Educational Development 1 (1): 17-24.

Torres, C. A. 2017. Theoretical and Empirical Foundations of Critical Global Citizenship Education, 69-83. New York: Routledge.

Torres, C. A., and P. Noguera. 2009. Social Justice for Teachers. Paulo Freire and Education as a Possible Dream. The Hague, The Netherlands: Sense Publishers.

Touraine, A. 1997. Puorrons-nous Vivre Ensemble? égaux et Différentes. Paris: Libraire Arthéme Fayard. UN Department of Economic and Social Affairs. 2017. International Migration Report 2017: Highlights (ST/ESA/ SER.A/404). . Accessed November 13, 2019. https://www.un.org/en/development/desa/population/migration/publications/ migrationreport/docs/MigrationReport2017_Highlights.pdf

Vertovec, S., and S. Wessendorf. 2010. The Multiculturalism Backlash: European Discourses, Policies and Practices.

London: Routledge.

Wieviorka, M. ed. 1996. Une société fragmentée? Le Multiculturalisme en débat. Paris: La Decouverte.

Wieviorka, M. 2001. La différence. Paris: Edition Balland 